Artikel Penelitian

\title{
Prediksi Prognosis Penderita Trauma Kapitis Berdasarkan Gambaran CT scan Kepala
}

\section{Prognosis Prediction of Head Trauma Patients Based on Head CT Findings}

\author{
Kurniawati Husnah ${ }^{1}$, Bachtiar Murtala ${ }^{1}$, Sri Asriyani', Andi Alfian $Z^{2}$, Nasrullah Mustamir ${ }^{3}$, Nikmatia Latief $^{1}$ \\ ${ }^{1}$ Departemen Radiologi Fakultas Kedokteran Universitas Hasanuddin Makassar \\ ${ }^{2}$ Departemen IImu Kesehatan Masyarakat/IImu Kedokteran Keluarga Fakultas Kedokteran Universitas Hasanuddin \\ Makassar \\ ${ }^{3}$ Departemen Ilmu Bedah Saraf Fakultas Kedokteran Universitas Hasanuddin Makassar
}

\begin{abstract}
ABSTRAK
Trauma kapitis memiliki penyebab, patologi, tingkat keparahan dan prognosis yang berbeda-beda sehingga diperlukan prediktor terpercaya untuk menilai luaran pasien. CT scan berperan penting dalam mengevaluasi kerusakan struktural pada fase akut trauma kapitis. Penelitian ini bertujuan menilai gambaran CT scan kepala dalam memprediksi prognosis penderita trauma kapitis. Penelitian ini merupakan penelitian retrospektif terhadap 444 penderita trauma kapitis ringan sampai berat yang dilakukan pemeriksaan CT scan kepala di RSUP Dr. Wahidin Sudirohusodo Makassar selama periode Januari-Juni 2018. Peneliti mengidentifikasi gambaran CT scan yang berpengaruh terhadap mortalitas pasien. Hasil penelitian menunjukkan bahwa status sisterna basalis (compressed, OR=31.690, absent, $\mathrm{OR}=11.092, \mathrm{p}<0.0001$ ), midline shift $(\mathrm{OR}=2.889, \mathrm{p}<0.0001)$, dan pendarahan subarachnoid atau intraventrikel $(\mathrm{OR}=6,977, \mathrm{p}<0.0001)$ merupakan prediktor independen mortalitas penderita trauma kapitis.
\end{abstract}

Kata Kunci: CT, Marshall, mortalitas, Rotterdam, trauma kapitis

\begin{abstract}
Head trauma has different causes, pathology, severity, and prognosis, so reliable predictors are needed to assess the outcome of patients. Computed tomography (CT) scan plays an important role in assessing the structural damage in the acute phase of head trauma. This study aimed to assess head CT findings in predicting prognosis of patients with head trauma. This study was a retrospective study of 444 patients with mild-to-severe head trauma who performed head CT scan at Dr Wahidin Sudirohusodo hospital, Makassar, from January to June 2018. This research identified the CT findings that affect patient mortality. This research showed status of basal cistern (compressed, OR=31.690, absent, OR=11.092, $p<0.0001)$, midline shift $(O R=2.889, p<0.0001)$, and subarachnoid or intraventricular hemorrhage $(O R=6.977, p<0.0001)$ are independent predictors of mortality in patients with head trauma.
\end{abstract}

Keywords: CT, head trauma, Marshall, mortality, Rotterdam

Korespondensi: Kurniawati Husnah. Departemen Radiologi Fakultas Kedokteran Universitas Hasanuddin Makassar, Jalan Perintis Kemerdekaan KM. 11, Makassar, Sulawesi Selatan, 90245 Tel. (0411) 581666 Email: kurniawatihusnah@gmail.com

DOI: http://dx.doi.org/10.21776/ub.jkb.2019.030.04.12 


\section{PENDAHULUAN}

Trauma kapitis didefinisikan sebagai benturan, penetrasi, atau pergerakan cepat dari otak di dalam tengkorak yang mengakibatkan perubahan status mental. Sering disebut sebagai the silent epidemic, trauma kapitis merupakan salah satu penyebab tersering kematian anak muda (1). World Health Organization (WHO) memprediksi bahwa pada tahun 2030, trauma kapitis akan menjadi penyebab kecacatan dan kematian secara global. Prediksi ini berdasarkan fakta peningkatan frekuensi kecelakaan lalu lintas di negara berkembang dan populasi usia lanjut yang rawan mengalami cedera di negara maju (2). Berdasarkan data Riskesdas tahun 2013, prevalensi tertinggi cedera di Indonesia secara nasional ditemukan di Sulawesi Selatan dengan jatuh dan kecelakaan sepeda motor menjadi penyebab cedera terbanyak (3). Data epidemiologis trauma kapitis di Rumah Sakit Dr. Wahidin Sudirohusodo Makassar menunjukkan peningkatan angka trauma kapitis 861 kasus trauma kapitis pada tahun 2005 menjadi 1078 kasus pada tahun 2007 (4).

Meskipun gejala klinis pasien trauma kapitis biasanya membaik dalam hitungan hari sampai minggu, akan tetapi dapat mengakibatkan defisit kognitif dan perilaku jangka panjang. Lebih jauh, terdapat bukti yang menyatakan bahwa trauma kapitis sedang sampai berat, bahkan trauma kapitis ringan berulang, dapat meningkatkan risiko penyakit neurodegeneratif seperti penyakit Parkinson (5). Klasifikasi pasien trauma kapitis penting untuk menggambarkan secara akurat kondisi pasien dan dilakukan dengan mengelompokkan pasien berdasarkan karakteristik spesifik pasien. Pada praktik klinis, pasien trauma kapitis umumnya dikelompokkan berdasarkan tingkat kesadaran pasien yang diukur dengan Glasgow Coma Scale (GCS). Meskipun demikian, pada pasien dengan cedera berat yang dilakukan intubasi dan ventilasi, pasien yang mengalami paralisis akibat obatobatan untuk mengontrol peningkatan tekanan intrakranial, atau pada pasien yang diberi sedasi, penilaian GCS tidak dapat dilakukan secara akurat. Sebagai alternatif, pada pasien dengan kondisi tersebut dapat diklasifikasikan berdasarkan kriteria morfologi pada pemeriksaan CT scan kepala $(6,7)$.

CT scan kepala menjadi modalitas pilihan untuk mengidentifikasi adanya dan perluasan dari kerusakan struktural pada fase akut trauma kapitis. Pada tahun 1991, Marshall et al., mengajukan sistem skor untuk mengelompokkan pasien trauma kapitis berdasarkan karakterstik CT scan kepala. Sistem ini telah divalidasi, memiliki inter-rater reliability (IRR) yang baik, dan telah digunakan luas untuk memprediksi tekanan intrakranial, mortalitas dan luaran fungsional (6). Walaupun sistem skor Marshall memiliki prediktibilitas yang baik, sistem ini memiliki beberapa kekurangan. Pada tahun 2005, sistem skor Rotterdam yang merupakan pengembangan dari sistem Marshall diajukan untuk mengatasi hal ini. Temuan CT scan awal yang dinilai pada sistem Marshall dan Rotterdam yaitu status sisterna basalis, midline shift, volume pendarahan, pendarahan epidural, dan pendarahan subarachnoid/intraventrikel (8). Penelitian ini membahas tentang temuan $C T$ scan yang dinilai pada kedua sistem tersebut. Pasien trauma kapitis umumnya dinilai dengan titik akhir penilaian adalah luaran jangka panjang, seperti mortalitas 6 bulan setelah trauma, dan dilakukan umumnya pada pasien trauma kapitis sedang dan berat (9). Sepanjang pengetahuan penulis, belum banyak penelitian yang menilai gambaran CT scan kepala untuk memprediksi secara dini luaran pasien trauma kapitis ringan sampai berat. Penelitian ini bertujuan menilai gambaran CT scan kepala dalam memprediksi prognosis penderita trauma kapitis.

\section{METODE}

\section{Desain Penelitian}

Data diperoleh dari rekam medis dan hasil CT scan kepala penderita trauma kapitis yang menjalani pemeriksaan $C T$ scan kepala di RSUP Dr. Wahidin Sudirohusodo Makassar pada bulan Januari-Juni 2018. Izin penelitian diperoleh dengan persetujuan Komite Etik Penelitian Kesehatan, Fakultas Kedokteran Universitas Hasanuddin, Makassar, Nomor 924/H4.8.4.5.31/PP36-KOMETIK/2018.

Seluruh hasil CT scan kepala penderita trauma kapitis dengan onset $<24$ jam setelah trauma dinilai. Hasil CT scan kepala dibaca oleh residen dan dikonfirmasi oleh seorang ahli radiologi senior. Penderita dengan hasil CT scan kepala yang menunjukkan kelainan selain akibat trauma akut, seperti pendarahan subakut/kronik, infeksi, neoplasma, tidak disertakan dalam penelitian. Parameter yang tampak pada CT scan kepala, meliputi status sisterna basalis, midline shift, volume pendarahan, pendarahan epidural, dan pendarahan subarachnoid/intraventrikel dinilai. Luaran saat keluar rumah sakit (hidup atau mati) dicatat.

Status sisterna basalis adalah kondisi sisterna ambien yang tampak pada CT scan kepala dan diklasifikasikan normal, compressed, absent. Midline shift dinyatakan sebagai pergeseran septum pellucidum diklasifikasikan sebagai ada $(>5 \mathrm{~mm})$ dan tidak ada $(\leq 5 \mathrm{~mm})$. Volume pendarahan adalah jumlah seluruh pendarahan intrakranial yang tampak pada CT scan kepala, selain pendarahan intraventrikel dan subarachnoid, diklasifikasikan besar $(>25 c c)$ dan kecil $(\leq 25 c c)$. Pendarahan epidural, pendarahan subarachnoid/ intraventrikel diklasifikasikan sebagai 'tidak tampak' dan 'tampak'. Data analisis statistik (SPSS ver 21.0) menggunakan uji chi square dan regresi logistik ganda.

\section{HASIL}

\section{Karakteristik Sampel Penelitian}

Peneliti memperoleh 473 sampel yang memenuhi kriteria inklusi penelitian. Dari 473 sampel tersebut, ditemukan hasil pencitraan CT scan kepala selain akibat trauma kepala akut pada 29 sampel sehingga menyisakan 444 sampel yang memenuhi kriteria. Katrakteristik sampel penelitian disajikan pada Tabel 1. Hasil menunjukkan bahwa mayoritas sampel penelitian adalah laki-laki (68\%), dengan kelompok umur terbanyak $11-20$ tahun (30\%). Sampel terbanyak mengalami trauma kapitis ringan $(64,4 \%)$ dengan mortalitas saat keluar rumah sakit sebesar $14,4 \%$.

Tabel 1. Karakteristik sampel penelitian

\begin{tabular}{lrrr}
\hline & Kategori & $\mathbf{n}$ & \% \\
\hline \multirow{2}{*}{ Jenis kelamin } & Laki-laki & 302 & 68,0 \\
& Perempuan & 142 & 32,0 \\
\multirow{3}{*}{ Umur (tahun) } & $1-10$ & 52 & 11,7 \\
& $11-20$ & 133 & 30,0 \\
& $21-30$ & 85 & 19,1 \\
\hline
\end{tabular}


Tabel 1. Karakteristik sampel penelitian (Lanjutan)

\begin{tabular}{lrrr}
\hline & Kategori & n & \% \\
\hline Umur (tahun) & $31-40$ & 64 & 14,4 \\
& $41-50$ & 49 & 11,0 \\
& $51-60$ & 28 & 6,3 \\
& $>60$ & 33 & 7,4 \\
Derajat & Ringan & 286 & 64,4 \\
trauma & Sedang & 110 & 24,8 \\
kapitis & Berat & 48 & 10,8 \\
Luaran & Hidup & 380 & 85,6 \\
& Mati & 64 & 14,4 \\
\hline
\end{tabular}

\section{Prediktor Radiologik Mortalitas Penderita Trauma Kapitis}

Tabel 2 menunjukkan bahwa seluruh gambaran CT scan kepala yang diteliti berhubungan secara signifikan $(p<0,05)$ terhadap luaran penderita trauma kapitis. Selanjutnya dilakukan analisis multivariat menggunakan uji regresi logistik ganda untuk mengetahui gambaran CT scan kepala yang paling signifikan berhubungan dengan mortalitas penderita trauma kapitis.

Tabel 2. Distribusi gambaran CT scan kepala berdasarkan luaran penderita trauma kapitis

\begin{tabular}{llrrr}
\hline \multirow{2}{*}{ Gmbaran CT scan } & \multicolumn{2}{c}{ Luaran } & \multirow{2}{*}{ p } \\
\cline { 3 - 4 } & & Mati (\%) & Hidup (\%) & \\
\hline \multirow{2}{*}{ Sisterna basalis } & Absent & $27(73)$ & $10(27)$ & $<0,001$ \\
& Compressed & $27(19,9)$ & $109(80,1)$ & \\
\multirow{4}{*}{ Midline shift } & Normal & $10(3,7)$ & $261(96,3)$ & \\
& Ada & $30(42,9)$ & $40(57,1)$ & $<0,001$ \\
Volume pendarahan & Tidak ada & $34(9,1)$ & $340(90,9)$ & \\
& Besar & $34(38,6)$ & $54(61,4)$ & $<0,001$ \\
EDH & Kecil & $30(8,4)$ & $326(91,6)$ & \\
& Ada & $23(20,5)$ & $89(79,5)$ & $<0,001$ \\
SAH/IVH & Tidak ada & $41(12,3)$ & $291(87,7)$ & \\
& Ada & $35(45,5)$ & $42(54,5)$ & $<0,001$ \\
\hline
\end{tabular}

Keterangan: Uji chi square

Tabel 3 menunjukkan bahwa gambaran CT scan kepala yang berhubungan secara bermakna dengan mortalitas penderita trauma kapitis adalah midline shift, sisterna basalis compressed dan absent, serta pendarahan subarachnoid/intraventrikel. Didapatkan persamaan logit untuk prediksi mortalitas penderita trauma kapitis sebagai berikut:

$$
\begin{aligned}
\text { Logit }_{\text {(luaran=mati) }}= & -2,815+1,061 * \text { ada midline shift }+ \\
& 2,406 * \text { sisterna absent }+3,456 * \text { sisterna } \\
& \text { compressed }
\end{aligned}
$$

\section{$+1,943 *$ ada SAH/IVH}

Dari persamaan diatas, diperoleh bahwa penderita trauma kapitis dengan sisterna basalis compressed memiliki probabilitas tertinggi untuk meninggal, yaitu $31,69 \%$, diikuti penderita dengan sisterna basalis absent $11,09 \%$, ada pendarahan subarachnoid/intraventrikel $6,98 \%$, dan probabilitas terendah yaitu ada midline shift $2,89 \%$. Model prediksi mortalitas penderita trauma kapitis diatas merupakan model yang baik (fit) dengan $\mathrm{p}=0,000$ (omnibus table) dan signifikan parsial $<0,100$. Berdasarkan overall percentage yaitu persentase kesesuaian data aktual dengan hasil prediksi model sebesar $89,9 \%$ artinya masih terdapat $10,1 \%$ responden yang salah diklasifikasikan (misclassification) pada model diatas. Berdasarkan nilai Nagelkerke $R$-square sebesar $46,9 \%$ artinya mortalitas penderita trauma kapitis mampu diterangkan oleh parameter CT scan yang dinilai sebesar $46,9 \%$, sisanya $53,1 \%$ diterangkan oleh variabel independen lainnya yang tidak ditemukan di dalam model.

\section{Tabel 3. Hasil akhir analisis multivariat gambaran CT scan kepala yang berpengaruh terhadap mortalitas penderita trauma kapitis}

\begin{tabular}{lccrrrr}
\hline \multirow{2}{*}{ Gambaran CT scan } & \multirow{2}{*}{ B } & \multirow{2}{*}{ p } & OR & \multicolumn{2}{c}{ 95\% Cl } \\
\cline { 5 - 7 } & & & & Lower & Upper \\
\hline Sisterna absent & 2,406 & 0,000 & 11,092 & 4.310 & 28.547 \\
Sisterna compressed & 3,456 & 0,000 & 31,690 & 10.884 & 92.270 \\
Midline shift & 1,061 & 0,007 & 2,889 & 1.334 & 6.255 \\
SAH/IVH & 1,943 & 0,000 & 6,977 & 3.377 & 14.416 \\
\hline
\end{tabular}

Keterangan: Uji regresi logistik ganda

\section{DISKUSI}

Hasil penelitian ini menunjukkan bahwa sisterna basalis merupakan prediktor yang paling dominan terhadap mortalitas penderita trauma kapitis. Mortalitas penderita trauma kapitis dengan sisterna basalis yang absent dan compressed lebih besar dibandingkan penderita dengan sisterna normal. Hasil penelitian ini sesuai dengan penelitian sebelumnya yang menyatakan bahwa sisterna basalis merupakan prediktor luaran penderita trauma kapitis (7,9-11). Peranan sisterna basalis sebagai indikator peningkatan tekanan intrakranial telah dibuktikan oleh banyak penelitian (11). Tekanan intrakranial yang meningkat akan menurunkan perfusi serebral dan menyebabkan efek penekanan terhadap jaringan sekitar (12). Hal ini dapat menjelaskan sisterna basalis yang compressed maupun absent dapat meningkatkan mortalitas penderita trauma kapitis, sebagaimana yang didapatkan pada penelitian ini.

Pendarahan subarachnoid meningkatkan risiko mortalitas dan ditemukan berhubungan secara signifikan dengan luaran yang buruk pada penderita trauma kapitis. Hasil penelitian ini sesuai dengan penelitian sebelumnya $(7,9)$. Pendarahan subarachnoid dihubungkan dengan terjadinya deteriorasi penderitra trauma kapitis karena pendarahan subarachnoid dapat menginduksi vasospasme, diselektrolemia, disfungsi hipofisis atau hypothalamus, dan hidrosefalus (13).

Hasil penelitian ini menunjukkan bahwa midline shift merupakan prediktor mortalitas pada penderita trauma kapitis. Hasil penelitian ini sesuai dengan penelitian yang dilakukan oleh Mata-Mbemba et al., dan Munakomi yang menyatakan bahwa midine shift merupakan prediktor mortalitas penderita trauma kapitis. Midline shift yang merupakan penanda tekanan intrakranial abnormal juga menjadi indikator penurunan perfusi otak akibat efek massa (14). Pada penelitian ini, didapatkan nilai OR midline shift lebih rendah dibanding parameter sisterna basalis dan pendarahan subarachnoid. Hal ini dapat disebabkan derajat midline shift sendiri dipengaruhi oleh lokasi lesi intraserebral dan adanya kelainan intrakranial bilateral. Selain itu, adanya dan derajat midline shift dapat mengalami perubahan signifikan setelah evakuasi lesi massa (15). 
Pada penderita trauma kapitis dengan atau tanpa pendarahan epidural, penderita dengan luaran yang baik lebih banyak dibandingkan penderita dengan luaran buruk - Mata-Mbemba et al., menyatakan bahwa pendarahan epidural tidak menjadi prediktor mortalitas penderita trauma kapitis. Pendarahan epidural dapat mematikan, namun mortalitas pasien dapat berkurang jika didiagnosis sebelum kerusakan otak ireversibel dan herniasi terjadi (6).

Penelitian ini juga menemukan bahwa volume pendarahan yang besar meningkatkan mortalitas penderita trauma kapitis, namun tidak berhubungan secara signifikan dengan luaran yang buruk. Temuan ini sesuai dengan penelitian Thelin et al., yang menemukan bahwa indikator efek massa sepertivolume lebih dari $25 \mathrm{~mL}$, menunjukkan nilai prediktif yang rendah terhadap luaran penderita trauma kapitis. Hal ini dapat menjadi indikasi bahwa lesi massa tidak lagi memberikan dampak kerusakan besar yang dapat disebabkan peningkatan sistem layanan kesehatan, seperti meningkatnya manajemen prerumah sakit, pemeriksaan radiologi yang cepat, dan evakuasi hematoma (16)

Mortalitas pasien belum dapat dijelaskan secara menyeluruh oleh parameter CT scan yang dinilai pada

\section{DAFTAR PUSTAKA}

1. Prins M, Greco T, Alexander D, and Giza CC. The Pathophysiology of Traumatic Brain Injury at a Glance. Disease Models \& Mechanisms. 2013; 6(6): 1307-1315.

2. Raj R. Prognostic Models in Traumatic Brain Injury. [Disertasi]. University of Helsinki, Helsinki. 2014.

3. Badan Penelitian dan Pengembangan Kesehatan Kementerian Kesehatan Republik Indonesia. Riset Kesehatan Dasar (Riskesdas). Jakarta: Badan Penelitian dan Pengembangan Kesehatan Kementerian Kesehatan RI: 2013; hal. 101-102.

4. Zainuddin SZ, Kwandou L, Akbar M, Muis A, Kaelan C, dan Patellongi I. Hubungan Amnesia Post Trauma Kepala dengan Gangguan Neurobehavior pada Penderita Cedera Kepala Ringan dan Sedang. ( O n I i n e ) 2015 . http://repository.unhas.ac.id/handle/123456789/9 622 [diakses tanggal 11 September 2018].

5. Hutson CB, Lazo CR, Mortazavi F, Giza CC, Hovda D, and Chesselet MF. Traumatic Brain Injury in Adult Rats Causes Progressive Nigrostriatal Dopaminergic Cell Loss and Enhanced Vulnerability to the Pesticide Paraquat. Journal of Neurotrauma. 2011; 28(9): 1783-1801.

6. Maas AIR, Hukkelhoven CWPM, Marshall LF, and Steyerberg EW. Prediction of Outcome in Traumatic Brain Injury with Computed Tomographic Characteristics: A Comparison between the Computed Tomographic Classification and Combinations of Computed Tomographic Predictors. Neurosurgery. 2005; 57(6): 1173-1182.

7. Munakomi S. A Comparative Study Between Marshall and Rotterdam CT Scores in Predicting Early Deaths in Patients with Traumatic Brain Injury in a Major Tertiary Care Hospital in Nepal. Chinese penelitian ini. Hal ini disebabkan masih terdapat variabel prognostik lain yang dapat mempengaruhi mortalitas penderitra trauma kapitis yang tidak dimasukkan ke dalam penelitian. Variabel prognostik berupa parameter klinis (seperti usia, GCS, reaktivitas pupil), parameter laboratorium (seperti kadar glukosa darah, konsentrasi hemoglobin, level natrium, marker koagulasi), tekanan darah, dan parameter CT scan lain, seperti pendarahan subdural, tidak dinilai pada penelitian ini (2). Selain itu, analisis luaran pada penelitian ini didasarkan pada status saat keluar rumah sakit yang dapat menyebabkan bias karena lama rawat inap yang berbeda pada setiap pasien. Pasien dengan rawat inap yang lama dapat mengalami komplikasi sekunder yang dapat menyebabkan peningkatan jumlah kematian yang tidak sesuai dengan yang seharusnya.

Dapat disimpulkan bahwa prediktor independen mortalitas penderita trauma kapitis adalah kondisi sisterna basalis, pendarahan subarachnoid/intraventrikel, dan midline shift. Diharapkan hasil penelitian ini dapat membantu klinisi dalam proses triase dan tatalaksana penderita trauma kapitis yang menunjukkan fitur spesifik diatas pada pemeriksaan CT scan kepala.

Journal of Traumatology. 2016; 19(1): 25-27.

8. Deepika A, Prabhuraj AR, Saikia A, and Shukla D. Comparison of Predictability of Marshall and Rotterdam CT Scan Scoring System in Determining Early Mortality after Traumatic Brain Injury. Acta Neurochirurgica. 2015; 157(11): 2033-2038.

9. Mata-Mbemba D, Mugikura S, Nakagawa A, et al. Early CT Findings to Predict Early Death in Patients with Traumatic Brain Injury: Marshall and Rotterdam CT Scoring Systems Compared in the Major Academic Tertiary Care Hospital in Northeastern Japan. Academic Radiology. 2014; 21(5): 605-611.

10. Jacobs B, Beems T, van der Vliet TM, Borm GF, and Vos PE. The Status of the Fourth Ventricle and Ambient Cisterns Predict Outcome in Moderate and Severe Traumatic Brain Injury. Journal of Neurotrauma. 2010; 27(2): 331-340.

11. Yılmaz A, Avcil M, Kızılay Z, Özdener KM, Çırak B, and Tahta K. Evaluation of the Relationship of Intracranial Pressure with the Levels of Hypothalamic-PituitaryGonadal Axis Hormones on Prognosis in Severe Brain Injury. Meandros Medical and Dental Journal. 2017; 18: 13-19.

12. Kouvarellis AJ, Rohlwink UK, Sood V, Van Breda B, Gowen MJ, and Figaji AA. The Relationship between Basal Cisterns on CT and Time-Linked Intracranial Pressure in Paediatric Head Injury. Child's Nervous System. 2011; 27(7): 1139-1144.

13. Modi NJ, Agrawal M, and Sinha VD. Post-Traumatic Subarachnoid Hemorrhage: A Review. Neurology India. 2016; 64 Suppl: S8-S13

14. Liao CC, Chen YF, and Xiao F. Brain Midline Shift Measurement and Its Automation: A Review of Techniques and Algorithms. International Journal of Biomedical Imaging. 2018; 2018: 1-13. 
15. Chesnut RM, Ghajar J, Maas AIR, et al. Guidelines for the Management and Prognosis of Severe Traumatic Brain Injury Part II: Early Indicators of Prognosis in Severe Traumatic Brain Injury. Journal Neurotrauma. 2000; 17(6): 555-627.
16. Thelin EP, Nelson DW, VehvilainenJ, et al. Evaluation of Novel Computerized Tomography Scoring Systems in Human Traumatic Brain Injury: An Observational, Multicenter Study. PLoS Medicine. 2017; 14(8): 119. 